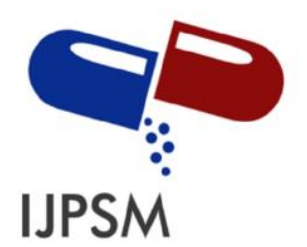

Anupama Yadav, International Journal of Pharmaceutical Sciences and Medicine (IJPSM),

Vol.6 Issue. 7, July- 2021, pg. 14-24

ISSN: 2519-9889

Impact Factor: 3.426

\title{
Buchholzia coriacea: AN OFTEN NEGLECTED AFRICAN PLANT WITH MULTIFARIOUS ETHNOPHARMACOTHERAPEUTIC POTENTIALS
}

\author{
Anupama Yadav* \\ Department of Pharmacognosy, School of Pharmacy, Chouksey College of Engineering, NH-49, Masturi - \\ Jairamnagar Road, Lalkhadan, Bilaspur 495004, Chhattisgarh
}

*Corresponding Author: Anupama Yadav

Department of Pharmacognosy, School of Pharmacy, Chouksey College of Engineering, NH-49, MasturiJairamnagar Road, Lalkhadan, Bilaspur 495004, Chhattisgarh

E-mail: yadavanupama4@gmail.com

DOI: 10.47760/ijpsm.2021.v06i07.002

\begin{abstract}
The evergreen shrub Buchholzia coriacea (Wonderful cola), which belongs to the Capparidaceae family, is found in Cameroon, Central African Republic, Gabon, Congo, Angola, Nigeria, and Ghana, among other places. Diarrhea, malaria, rheumatism, ulcers, worm infestation, asthma and cough, diabetes, hypertension, mental problems, and impotence were among the conditions for which traditional medicine believed it to be a useful alternative treatment. Some of its ethnomedicinal knowledge had been ethnopharmacologically verified and published in scientific publications. As a result, the emphasis of this study is on a current evaluation of its verified ethnomedicinal activities, which will serve as a research horizon for current and future academics. KEYWORDS: Buchholzia coriacea, Ethnopharmacological, Ethnomedicinal, Phytochemicals, Pharmacotherapy, Natural
\end{abstract}

\section{INTRODUCTION}

Herbal medicine, a widely accepted alternative type of medicine, entails the use of plant materials in the diagnosis, prevention, and treatment of physical, mental, and social illnesses. Since man's creation, relevant knowledge on the efficacy of herbal therapy has been traced back to previous experiences and observations. For the development of alternative treatments to synthetic medicines, scientific validation of plants with valuable ethnomedicinal knowledge is required. Information on several scientifically verified plants, including Citrullus lanatus, Tridax procumbens, Xylopia aethiopica, and Ocimum gratissimum, was also collected from various 


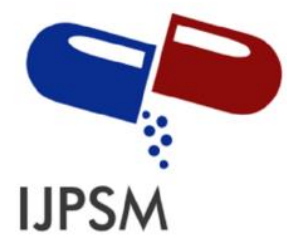

Anupama Yadav, International Journal of Pharmaceutical Sciences and Medicine (IJPSM), Vol.6 Issue. 7, July- 2021, pg. 14-24

ISSN: 2519-9889

Impact Factor: 3.426

databases and published in scientific publications. However, an up-to-date collection of scientifically verified material on Buchholzia coriacea for its folkloric claims in medicine is still lacking, which is essential for research and medication development on the cutting edge. As a result, this review was triggered. B. coriacea, a member of the Capparidaceae family, was named after RW Buchholz, a botanist who collected plants in Cameroon in the late 1800s. It is a small to medium-sized evergreen tree that grows up to $20 \mathrm{~m}$ tall and is found in Cameroon, the Central African Republic, Gabon, Congo, Angola, Ghana, and Nigeria, among other places. B. coriacea's bark is smooth, blackish-brown, or dark green in color. It has a thick crown, big glossy leathery leaves grouped spirally and clustered at the branch tips, and prominent cream-white flowers in racemes at the branch ends. $B$. coriacea is a plant that is occasionally grown as a medicinal and fetish plant in Gabon [1].

\section{TAXONOMY PROFILE}

Kingdom: Plantae

Phylum: Tracheophyta

Class: Spermatopsida

Subclass: Magnoliidae

Order: Brassicales

Superorder: Rosanae

Family: Capparaceae

Genus: Buchholzia

Species: coriaceae [2]

\section{COMMON AND LOCAL NAMES}

Wonderful cola, musk tree, Cola pime, and Elephant cola are all common names for B. coriacea. It is referred to as 'Ndo' in Mende (Sierra Leone), 'Doe-fiah' in Kru-basa (Liberia), 'Eson-bese' 


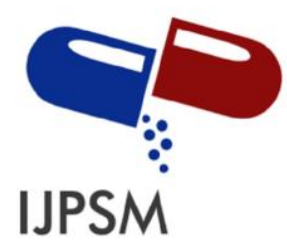

Anupama Yadav, International Journal of Pharmaceutical Sciences and Medicine (IJPSM), Vol.6 Issue. 7, July- 2021, pg. 14-24

ISSN: 2519-9889

Impact Factor: 3.426

in Akan-asante (Ghana), 'Banda' in Munga (West Cameroons), 'Esson bossi' in Central Africa, 'Kola Pimente' in French, '6wi' in Edo State,'Okpo (Nigeria) [3].

\section{ETHNOMEDICINAL USES}

B. coriacea has a variety of therapeutic properties. Because of its use in traditional medicine, this seed was given the moniker "excellent kola." The seeds, which may be cooked or eaten raw, are the most frequently consumed plant components. It is beneficial in the treatment of hypertension and the prevention of premature aging in Africa. It is a memory-enhancing brain meal. When rubbed to the forehead in Africa, beautiful kola may stop migraine headaches. To alleviate back discomfort, the stem bark extract is used as an enema. Pleurisy, rheumatism, conjunctivitis, smallpox, scabies, and other skin problems are treated with unspecified bark formulations. Women's sterility is treated using leaf decoctions. Filarial nematodes are treated with leaf infusions, and powdered or pulped leaves are used to cure fever, ulcers, boils, and hemorrhoids. Anodyne is made from ground fruits. Fruit extracts are used as an anthelmintic, and fruit kernels are eaten to alleviate angina and nasal bleeding. Asthma and cough may be treated with fruit scrapings. Fever, diabetes, hypertension, cough, mental problems, and impotence are all treated using seed formulations. Snakebites are treated with seed pulp. Seed oil is used to treat menstrual difficulties and gastrointestinal issues. In the production of the arrow, the bark is utilized as a component. Capsicum pepper may be replaced with seeds, which have a spicy flavor. The seed is eaten as a replacement for kola nuts in Côte d'Ivoire. Wood is occasionally utilized in the building of houses [4].

\section{PHARMACOLOGICAL POTENTIALS}

\section{Anti-diabetic activity}

The methanol seed extract of B. coriacea was shown to have hypoglycemic effects that were synergistic with metformin, a common oral hypoglycaemic drug. After 4 hrs of therapy, 


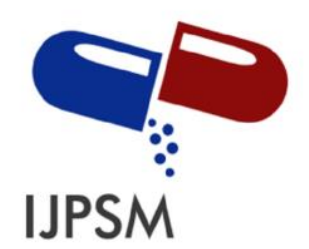

Anupama Yadav, International Journal of Pharmaceutical Sciences and Medicine (IJPSM), Vol.6 Issue. 7, July- 2021, pg. 14-24

ISSN: 2519-9889

Impact Factor: $\mathbf{3 . 4 2 6}$

oral administration of $B$. coriacea at dosages of $100 \mathrm{mg} / \mathrm{kg}, 200 \mathrm{mg} / \mathrm{kg}$, and $400 \mathrm{mg} / \mathrm{kg}$ per oral resulted in PBGR reductions of 37.73 percent, 12.30 percent, and 11.30 percent, respectively. The combination of extract $(100 \mathrm{mg} / \mathrm{kg})$ with metformin $(100 \mathrm{mg} / \mathrm{kg})$ resulted in PBGRs of 73.4 percent and 72.2 percent on the fourth day and seventh day, respectively.

Oral treatment with $150 \mathrm{mg} / \mathrm{kg}, 300 \mathrm{mg} / \mathrm{kg}$, and $600 \mathrm{mg} / \mathrm{kg}$ of methanol fruit extract of $B$. coriacea produced substantial dose-dependent decreases in fasting blood glucose levels in streptozotocin-induced diabetic rats. In contrast to the results in negative control animals, blood concentrations of catalase and reduced glutathione were substantially greater in rats treated with glibenclamide $(2 \mathrm{mg} / \mathrm{kg})$ and different dosages $(150 \mathrm{mg} / \mathrm{kg}, 300 \mathrm{mg} / \mathrm{kg}$, and $600 \mathrm{mg} / \mathrm{kg})$ of the extract. The extract also reduced triglyceride and total cholesterol levels in the blood. In diabetic rats, the fruit extract decreased lipid peroxidation in a dose-dependent manner.

Adisa et al. (2011) evaluated the possible hypoglycemic activity and ameliorative effects of oral administration of ethanol extracts (EEBC) and butanol fraction (BFBC) of B. coriacea seeds in streptozotocin (STZ)-induced diabetic mice and rats and found that fasting blood glucose (FBG) in hyperglycemic mice and normoglycemic rats were significantly decreased within $4 \mathrm{hrs}$ in hyperglycemia. In STZ-induced diabetic rats, administration of the extract and glibenclamide resulted in a significant reduction in FBG, serum aspertate aminotransferase (AST), and alanine aminotransferase (ALT) levels, as well as serum creatinine, urea, total cholesterol, triglyceride, and thiobarbituric acid reactive species (TBARS) products. The combination of extract and glibenclamide enhanced serum superoxide dismutase activity substantially. According to Adisa et al. (2011), B. coriacea seeds contain a strong hypoglycemic and anti-oxidant agent, which is thought to be a flavone glycoside enriched in BFBC and may be helpful in treating diabetes-related secondary problems. 


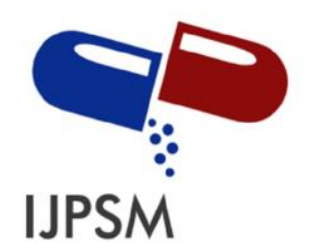

Anupama Yadav, International Journal of Pharmaceutical Sciences and Medicine (IJPSM), Vol.6 Issue. 7, July- 2021, pg. 14-24

ISSN: 2519-9889

Impact Factor: 3.426

\section{Anti-microbial activity}

The impact of fresh kola, hexane, and methanol extracts of B. coriacea on certain foodborne pathogens (Escherichia coli, Enterococcus faecalis, Staphylococcus aureus, Trichoderma viride, and Aspergillus niger) were studied by Ezekiel and Onyeoziri (2009). With the test microorganisms E. coli $(62 \mathrm{~mm})$, E. faecalis $(40 \mathrm{~mm})$, and $S$. aureus $(40 \mathrm{~mm})$, fresh kola exhibited inhibitory zones $(50 \mathrm{~mm})$. T. viride and A. niger, the two test fungi, were totally inhibited in their growth. With the test microorganisms E. coli $(21 \mathrm{~mm})$, E. faecalis $(20 \mathrm{~mm})$, and $S$. aureus $(20 \mathrm{~mm})$, the hexane extract exhibited inhibitory zones ranging from $20 \mathrm{~mm}$ to 40 mm (40 mm). T. viride and A. niger, on the other hand, exhibited no inhibitory impact. Some of the test pathogens had inhibitory zones ranging from $20 \mathrm{~mm}$ to $30 \mathrm{~mm}$, according to the extract: E. coli $(30 \mathrm{~mm})$, E. faecalis $(25 \mathrm{~mm})$, S. aureus $(20 \mathrm{~mm})$, and T. viride $(20 \mathrm{~mm})$. On A. niger, it had no inhibitory effect.

When compared to the conventional antibiotics ampicillin and tioconazole, Ajaiyeoba et al. (2003), found that fractions produced from the methanol extract of B. coriacea stem bark had a strong concentration-dependent anti-bacterial and anti-fungal activity. In the brine shrimp lethality (BSL) test, the methanol extract was determined to be non-toxic with an $\mathrm{LC}_{50}$ of 1031 $\mu \mathrm{g} / \mathrm{mL}$. The two major components found in the most active fraction were lupeol and betasitosterol.

Chika and colleagues investigated the anti-bacterial activity of $B$. coriacea leaf extracts in 2012. The study utilized Gram-positive and Gram-negative clinical isolates, as well as ESBL positive E. coli isolates. By using in vitro agar well diffusion methods, the isolates were treated with $N$-hexane, methanol, and chloroform extracts of $B$. coriacea leaf for anti-bacterial activity. The findings indicate that extracts of $B$. coriacea leaf in $N$-hexane, methanol, and chloroform evoked moderate anti-bacterial activity against test isolates sensitive to E. coli, Staphylococcus aureus, Shigella species, Klebsiella pneumoniae, and Bacillus subtilis. $N$-hexane and methanol extracts had considerable inhibitory effects against the ESBL, while chloroform extract had no 


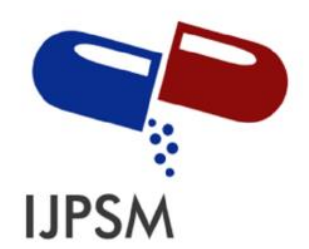

Anupama Yadav, International Journal of Pharmaceutical Sciences and Medicine (IJPSM), Vol.6 Issue. 7, July- 2021, pg. 14-24

ISSN: 2519-9889

Impact Factor: 3.426

impact. For all of the test isolates, the minimum inhibitory concentration (MIC) varied from 6.25 $\mathrm{mg} / \mathrm{mL}$ to $12.5 \mathrm{mg} / \mathrm{mL}$. All of the ESBL-positive E. coli isolates had MIC values of $50 \mathrm{mg} / \mathrm{mL}$. Their research revealed that B. coriacea leaf extracts had promising anti-bacterial properties, making them suitable for pharmaceutical and medical use.

The presence of phlobatannins, carbohydrates, proteins, tannins, saponins, alkaloids, and flavonoids in magnificent kola leaf was discovered via phytochemical research in this study. Against the $S$. aureus strains, the ethanol extract $(10-14 \mathrm{~mm})$ and methanol extract $(13-15 \mathrm{~mm})$ evoked different zones of inhibition. For certain strains of $S$. aureus, the MICs of both extracts were $50 \mathrm{mg} / \mathrm{mL}$ and $100 \mathrm{mg} / \mathrm{mL}$. Further high throughput methods, according to Ejikeugwu and coworkers, should be used to define the major bioactive components of the amazing kola plant extracts so that they may be combined into medication formulations for the treatment of bacterial infections.

The existence of active components in these two plants was tested. Separate screens were used for the leaves and the stem. Anti-fungal properties of the leaves and stem were tested using Aspergillus niger, Penicillum sp., Candida albicans, Fusarium oxysporium, and Aspergillus flavus. The activity of the extract was compared to methanol as control and tioconazole as a reference standard at $200 \mathrm{mg} / 100 \mathrm{~mL}$. The results of the anti-fungal test of plant extracts, according to Ogunmefun and Ajaiyeoba (2013), explain why they are used in traditional medicine.

\section{Anthelmintic activity}

In 2011, Nweze and colleagues used experimentally infected mice of both sexes to test the efficacy of a methanol seed extract of B. coriacea against a field strain of Trypanosoma congolense. The extract was given to the rats at doses of $250 \mathrm{mg} / \mathrm{kg}, 500 \mathrm{mg} / \mathrm{kg}$, and $1000 \mathrm{mg} / \mathrm{kg}$ for five days. The positive control mice were given diminazene diaceturate at a dose of 3.5 $\mathrm{mg} / \mathrm{kg}$ i.p. There was no statistically significant difference in body weights in the research. 


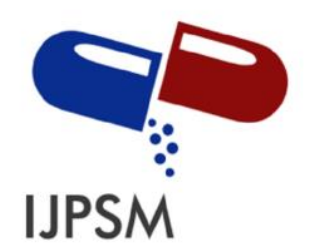

Anupama Yadav, International Journal of Pharmaceutical Sciences and Medicine (IJPSM), Vol.6 Issue. 7, July- 2021, pg. 14-24

ISSN: 2519-9889

Impact Factor: 3.426

Infected mice had a wide range of rectal temperatures. Infected animals had a substantially lower packed cell volume (PCV) than uninfected mice. The PCV of the extract-treated and untreated mice was not significantly different. The parasitaemia levels in the extract-treated and untreated mice steadily increased until all of the mice perished. There was a recurrence of infection six days after finishing the diminazene diaceturate therapy. The diminazene diaceturate-treated group had a $50 \%$ relapse rate at the conclusion of the study. At the dosages studied, the methanol extract of $B$. coriacea seeds had no anti-trypanosomal action against mice infected with $T$. congolense.

The anti-plasmodial efficacy of aqueous extract of $B$. coriacea was tested intraperitoneally in malaria-induced albino mice using parasitized human group $\mathrm{O}$ blood. Chloroquine was given to the experimental control mice, whereas B. coriacea aqueous extracts were given to the experimental animals. The parasitemia level of experimental animals that were treated with $120 \mathrm{mg} / \mathrm{kg}$ decreased from 80 parasites per field on the first day to zero by the third day, while those treated with $120 \mathrm{mg} / \mathrm{kg}$ reduced parasitemia level from 80 parasites per field on the first day to 7 parasites per field on the third day and 81 parasites per field to 5 parasites per field respectively. A reduction in appetite was noted throughout therapy, however, this reversed when the parasitemia level dropped. B. coriaceae and Gynandropsis gynandra methanol leaf and stem extracts were tested for their anthelmintic activities against Fasciola gigantica, Taenia solium, and Pheritima pasthuma, respectively. Piperazine citrate $(10 \mathrm{mg} / \mathrm{mL})$ was used as the reference medication, while distilled water was used as the control. All of the extracts showed significant anthelmintic activity at five concentrations $(10-100 \mathrm{mg} / \mathrm{mL})$, with B. coriaceae and G. gynandra stem methanol extracts being the most active.

\section{Anti-hypercholesterolemic activity}

When compared to untreated hypercholesterolemic rats, ethanol extract of B. coriacea (EEBC) substantially lowered blood and liver total cholesterol and LDL-cholesterol levels, as 


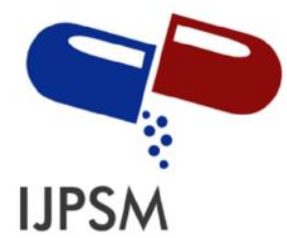

Anupama Yadav, International Journal of Pharmaceutical Sciences and Medicine (IJPSM), Vol.6 Issue. 7, July- 2021, pg. 14-24

ISSN: 2519-9889

Impact Factor: 3.426

well as lipid peroxidation. The activities of AST and ALT in hypercholesterolemic rats treated with EEBC were not significantly different from the control. B. coriacea seeds, according to Olaiya and colleagues, contain a powerful anti-hypercholesterolemic substance that may be used in clinical settings to treat hypercholesterolemia and associated consequences.

\section{Anti-ulcer activity}

When compared to controls, administration of $200 \mathrm{mg} / \mathrm{kg}$ and $400 \mathrm{mg} / \mathrm{kg}$ of B. coriacea seed extract substantially reduced the ulcerogenic impact of indomethacin in the stomach mucosa of Wistar rats.

\section{Gastric anti-secretory activity}

In isolated guinea-pig ileum, the extract decreased histamine-mediated stomach acid production and inhibited histamine-induced contractile responses, which was similar to the reference medication, chlorpheniramine. The extract has ulcer-protective properties.

\section{Male reproductive parameters}

The effects of $B$. coriacea methanol seed extract on the male reproductive system of albino rats were studied. The weight of the epididymis and seminal vesicle, excluding the testes and prostate gland, was significantly reduced after 6 weeks of administration of $200 \mathrm{mg} / \mathrm{kg} \mathrm{b}$.w. extract. The weight of the visceral organs, such as the lungs, liver, heart, and kidney, was unaffected. There was also a significant reduction in sperm motility and volume. The sperm count and morphology did not change much. The total tissue protein of the epididymis and testes of the treated rats rose substantially, and the treated rats were not fertile. The epididymal ducts were largely empty, according to histological findings (although the epithelial lining appeared normal). In the testes, there were fewer spermatozoa and late-stage spermatids with normal 


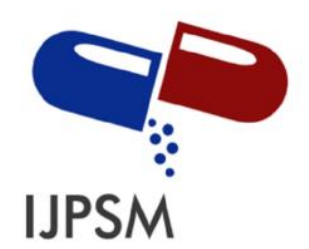

Anupama Yadav, International Journal of Pharmaceutical Sciences and Medicine (IJPSM), Vol.6 Issue. 7, July- 2021, pg. 14-24

ISSN: 2519-9889

Impact Factor: $\mathbf{3 . 4 2 6}$

testicular epithelium. As a result, Obembe and colleagues hypothesized that B. coriacea extract may have anti-infertility properties.

\section{Anti-pyretic activity}

The methanol extract of $B$. coriacea leaves was also studied for its phytochemical characteristics and anti-pyretic effects. Tannins, flavonoids, alkaloids, glycosides, and saponins were found in the leaves of B. coriacea, according to phytochemical analysis. B. coriacea leaf extract (50 mg/kg, p.o.) alleviated pyrexia in a way that was similar to Aspirin $(100 \mathrm{mg} / \mathrm{kg})$. The $\mathrm{LD}_{50}$ of the extract revealed that at a dosage of $5000 \mathrm{mg} / \mathrm{kg}$, the extract is well tolerated.

\section{Gastrointestinal activities}

The methanol extract of $B$. coriacea leaves has also been shown to have phytochemical, antispasmodic, and anti-diarrheal effects. Ibrahim and Fagbohum also investigated the phytochemical and mineral properties of B. coriacea dry seeds in 2013. The seeds of B. coriacea included moisture (1.30 percent), crude fat (2.30 percent), crude protein (13.34 percent), ash (6.6 percent), crude fiber (2.19 percent), and carbohydrate (2.19 percent), according to proximate analysis (75.43 percent). Sodium (1.22 ppm), potassium (1.34 ppm), phosphorous (0.22 mg/g), calcium (0.19 percent), magnesium (1.62 percent), zinc (0.18 percent), iron (1.11 percent), and manganese were all found in the mineral analysis (0.46 percent). Alkaloids (3.16 percent and 3.32 percent), glycoside (2.16 percent and 2.46 percent), saponin ( 2.10 percent and 2.23 percent), steroids $(0.14$ percent and 0.16 percent), tannin (6.46 percent and 6.73 percent), flavonoids $(0.68$ percent and 0.79 percent), terpenes (0.22 percent and 0.06 percent), reducing sugars (1.14 percent and 1.71 percent), and phenol (1.83 percent and 1.26 percent) were among the phytochemicals found in the ethanol and methanol extract. 


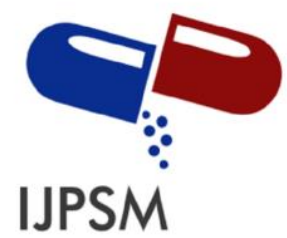

Anupama Yadav, International Journal of Pharmaceutical Sciences and Medicine (IJPSM), Vol.6 Issue. 7, July- 2021, pg. 14-24

ISSN: 2519-9889

Impact Factor: 3.426

\section{Hepatocellular Integrity}

Flavonoids, saponins, oxalates, tannins, phytates, cyanogenic glycosides, and alkaloids were discovered via phytochemical screening. The shelf-life of the investigated seed samples declined from oven-dried uncooked seed sample to fresh seed sample to cooked sample, according to the results of the proximate contents. When comparing the results of the AST, ALT, and alkaline phosphatase (ALP) of rats fed a compounded feed of fresh B. coriacea seed and oven-dried uncooked seed to the control group, the AST, ALT, and ALP. The anti-bacterial efficacy of the examined seed, particularly when fresh or in an uncooked state, cannot be contested based on the findings of this research; nevertheless, the pace at which any of these forms compromises hepatocellular integrity should be addressed [5].

\section{CONCLUSION}

The traditional utility and clinical potentials of $B$. coriacea, a medicinal plant widely utilized in many areas of the globe, were revealed in this study. However, ethnomedicinal claims of this magnificent plant related to anti-inflammatory, anti-hypertensive, anti-asthmatic, anti-tussive, and aphrodisiac, among others, have yet to be scientifically verified and are therefore suggested for more research. The general public's attention is drawn to the use of natural products in disease management, as well as the development of plant products into standardized, qualitycontrolled phytopharmaceuticals, and the characterization of their bioactive component, which can be used in the development of more reliable and safer drugs, as a result of this review.

\section{ACKNOWLEDGEMENT}

The author acknowledges the college management, principal, teachers, non-teaching staffs, and colleagues for their kind support. 


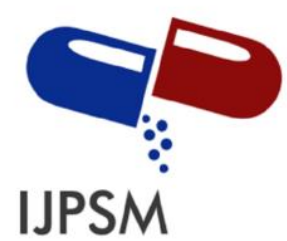

Anupama Yadav, International Journal of Pharmaceutical Sciences and Medicine (IJPSM), Vol.6 Issue. 7, July- 2021, pg. 14-24

ISSN: 2519-9889

Impact Factor: 3.426

\section{CONFLICT OF INTEREST}

The authors declare no Conflict of Interest regarding the publication of the article.

\section{FUNDING INFORMATION}

No funding agency is acknowledged.

\section{REFERENCES}

[1]. Izah SC, Uhunmwangho EJ, Eledo BO. Medicinal potentials of Buchholzia coriacea (wonderful kola). Med Plant Res. 2018;8(5):27-42.

[2]. Attibayeba OP, Abena AA. Buchholzia coriacea Engl. (Capparidaceae). J Anim Plant Sci. 2019;40(1):6501-13.

[3]. Ojinnaka CM, Nwachukwu KI, Ezediokpu MN. The Chemical Constituents and Bioactivity of the seed (Fruit) extracts of Buchholzia Coriacea Engler (Capparaceae). J Appl Sci Environ Manag. 2015;19(4):795801.

[4]. Adebayo SA, Oladele OI. Medicinal values of kola nut in Nigeria: implication for extension service delivery. Life Sci J. 2012;9(2):887-91.

[5]. Oghenesuvwe E, Benneth B, Emuesiri M, Paul C, Innocent O. Ethnopharmacological Review of Buchhoizia coriacea (Wonderful Kola). Int J Adv Pharm Biol Chem. 2015;4(1):149-55.

\section{$\underline{\text { Author Details }}$}

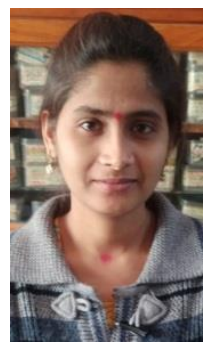

\section{Anupama Yadav}

Department of Pharmacognosy, School of Pharmacy, Chouksey College of Engineering, NH-49, Masturi - Jairamnagar Road, Lalkhadan, Bilaspur 495004, Chhattisgarh, INDIA 